\title{
Energetic aspect of diesel engine operation
}

\begin{abstract}
The paper provides a proposal of a quantitative interpretation of operation which (as the operation of Hamilton and Maupertius presented in classical mechanics and the operation issuing from change of the body momentum) is considered as a physical quantity with the measurement unit called a joule-second [joule $\times$ second]. An original method for analyzing and estimating the engine operation has been demonstrated in the energetic aspect for the operating needs. The homogenous Poison process and semi-Markov process have been herein applied to justify the usability of such interpreted operation. The two processes have made it possible to formulate a model deterioration of the diesel engine operation over time. Thus, the model is a random Poisson process or semi-Markov process. It has also been shown that the integral calculus can be (and should be) applied to identify the energetic properties of an engine. Considerations on the energetic aspect of diesel engine operation are provided on the example of marine engines of a ship's main propulsion system.

Key words: operation, energy, technical state, diesel engine, Poisson process, semi-Markov process
\end{abstract}

\section{Energetyczny aspekt działania silników o zapłonie samoczynnym}

\begin{abstract}
$W$ artykule zaproponowano interpretację wartościujaca działania, które (podobnie jak przedstawione w mechanice klasycznej działania Hamiltona i Maupertiusa oraz działanie wynikajace ze zmiany pędu ciała) jest rozpatrywane jako wielkość fizyczna o jednostce miary zwanej dżulosekunda [dżul $\times$ sekunda]. Przedstawiono oryginalna metodę analizy $i$ oceny działania silników o zapłonie samoczynnym w ujęciu energetycznym na potrzeby eksploatacyjne. Do uzasadnienia przydatności tak interpretowanego działania zastosowano jednorodny proces Poissona i proces semi-Markowa. Procesy te umożliwity skonstruowanie modelu przebiegu pogarszania się działania silnika o zapłonie samoczynnym z uptywem czasu jego funkcjonowania. Modelem tym jest więc proces losowy Poissona lub semi-Markowa. Wykazano też, że do identyfikacji walorów energetycznych silnika może (i powinien) być zastosowany rachunek całkowy. Rozważania dotyczace energetycznego aspektu działania silników o zapłonie samoczynnym przedstawiono na przykładzie silników okrętowych napędu glównego statków morskich.
\end{abstract}

Słowa kluczowe: działanie, energia, stan techniczny, silnik o zapłonie samoczynnym, proces Poissona, proces semi-Markowa

\section{Introduction}

While operating diesel engines we need to identify not only their technical states but also their energetic properties $[5,7,8,12,13,15]$. The properties characterize the medium torque $\left(\mathrm{M}_{\mathrm{o}}\right)$ and the engine speed $(\mathrm{n})$ of this type of engines. The torque $\mathrm{M}_{\mathrm{o}}$ and the speed $\mathrm{n}$ (as measurable values) enable to define a usable power $\left(\mathrm{N}_{\mathrm{e}}\right)[12,13,15]$.

The usable power $\left(\mathrm{N}_{\mathrm{e}}\right)$ is a quantity that characterizes the stream of energy converted in a form of usable work $\left(\mathrm{L}_{\mathrm{e}}\right)$ at a defined time $(\mathrm{t})$. From this reason the work Le can be interpreted as the output of the delivered power $\mathrm{N}_{e}=\dot{\mathrm{L}}_{\mathrm{e}}$ in time $\mathrm{t}$ and therefore expressed with the formula:

$$
\mathrm{L}_{\mathrm{e}}=\mathrm{N}_{\mathrm{e}} \cdot \mathrm{t}
$$

From formula (1) it results that the power $\mathrm{N}_{\mathrm{e}}$ is a quantity containing information how quickly the work $\mathrm{L}_{\mathrm{e}}$ has been (or can be) performed by a combustion engine.

However, in practice also a quantity is significant that provides information how long the work $\mathrm{L}_{\mathrm{e}}$ must be delivered by engine to a receiver (screw propeller of a ship, generator, compressor) in order for a given task to be performed. This quantity can be called operation [5-7]. Because each type of work being performed by engine (e.g. usable work, compression, expansion, etc.) is a form of energy conversion, in this

\section{Wprowadzenie}

W eksploatacji silników o zapłonie samoczynnym istotna jest identyfikacja nie tylko ich stanów technicznych, lecz także walorów energetycznych [5, 7, 8, 12, 13, 15]. Walory te charakteryzują: średni moment obrotowy $\left(\mathrm{M}_{\mathrm{o}}\right)$ oraz prędkość obrotowa wału korbowego (n) tego rodzaju silników. Moment $\mathrm{M}_{\mathrm{o}}$ i prędkość obrotowa n (jako wielkości mierzone) umożliwiają określenie mocy użytecznej $\left(\mathrm{N}_{\mathrm{e}}\right)$ $[12,13,15]$.

Moc użyteczna $\left(\mathrm{N}_{\mathrm{e}}\right)$ jest wielkością charakteryzującą strumień energii przetwarzanej w określonym czasie (t) w formie pracy użytecznej $\left(\mathrm{L}_{\mathrm{e}}\right)$. $\mathrm{Z}$ tego względu praca $\mathrm{L}_{\mathrm{e}}$ może być interpretowana jako wynik dostarczania mocy $\mathrm{N}_{\mathrm{e}}=\dot{\mathrm{L}}_{\mathrm{e}}$ w czasie $\mathrm{t} i$ wobec tego wyrażana wzorem (1).

$\mathrm{Z}$ wzoru (1) wynika, że moc $\mathrm{N}_{\mathrm{e}}$ jest wielkością, która zawiera informację, jak szybko praca $\mathrm{L}_{\mathrm{e}}$ została (lub może być) wykonana przez silnik spalinowy.

Jednakże w praktyce jest istotna także wielkość, która zawiera informację jak długo może być dostarczana przez silnik praca $\mathrm{L}_{\mathrm{e}}$ do odbiornika (np. śruby napędowej statku, prądnicy, sprężarki), aby mogło być wykonane określone zadanie. Tę wielkość można nazwać działaniem [5, 6, 7]. Ze względu na to, że każdy rodzaj pracy realizowanej przez silnik (np. praca: użyteczna, sprężania, rozprężania itd.) jest formą 
way understood operation (D) is a quantity expressing the energy (E) released over time ( $t$ ), and that is the reason for its defining with the formula:

$$
\mathrm{D}=\mathrm{E} \cdot \mathrm{t}
$$

The operation (2) determines the energy released over the time in which this energy was consumed. When the engine wear is considered, the operation equals to the energy drop (decrease) in time in which it proceeded $[4,8,11]$. The energy can reveal only when converted into a form of work or heat $[6,8,13,14]$. This also refers to the operation of other energetic systems, like spark-ignition engines, turbine engine and the like $[2,13,14]$.

In case of any diesel engine the usable energy $\left(E_{e}\right)$ generated by the engine with a defined usable power $\left(\mathrm{N}_{\mathrm{e}}\right)$, in strictly determined conditions, can be considered as a measure of its ability to perform the work $\mathrm{L}_{\mathrm{e}}$ at a defined time $\mathrm{t}$. Therefore the work as a form of energy conversion, generated by the engine, can be defined from the formula [13]

$$
\mathrm{L}_{\mathrm{e}}=2 \pi \mathrm{nM}_{\mathrm{o}} \mathrm{t}
$$

in the case when: $\mathrm{M}_{\mathrm{o}}=$ idem and $\mathrm{n}=$ idem.

When $\mathrm{M}_{\mathrm{o}} \neq$ idem and $\mathrm{n} \neq$ idem the work can be presented in the form of dependences:

$$
L_{e}=2 \pi \int_{0}^{t} n(\tau) M_{o}(\tau) d \tau
$$

In the operating practice of diesel engines (main engines) being applied to marine propulsion systems it is extremely important how long the work $\mathrm{L}_{\mathrm{e}}$ can be released for the needs of the propulsion system of the given ship. This refers especially to the ships the propulsion systems of which are fitted with such engines. In the case when due to the wear, the main engine cannot be loaded with the demanded usable power $\left(\mathrm{N}_{\mathrm{e}}\right)$ in time $\mathrm{t}$, it is not able to perform the demanded work $\mathrm{L}_{\mathrm{e}}$ in this time needed to ensure a generation of the demanded pressure force $(\mathrm{T})$ by the screw propeller of the ship. As a consequence even a full-scale rudder deflection is not enough for it to generate a sufficient force (S) that would compensate the effects of wind and wavy sea. This results first in losing the steerability (heading stability) by the ship (each ship) which is not able to move further in the demanded direction, then in losing its transverse stability. Thus in the case of a "broad reach" wind and the follow-up wave during a storm the ship is usually overturned, pushed into rocky coast or aground, etc. Generally such accidents turn into catastrophes [9].

From the above considerations follows that it is reasonable to analyze not only the power $\mathrm{N}_{\mathrm{e}}$ released in diesel engine's workspaces, and simultaneously work $\mathrm{L}_{e}$, but also the operation (D) of this type of engines, understood in this case as energy conversion in these workspaces that leads to obtaining the demanded usable work $\left(\mathrm{L}_{\mathrm{e}}\right)$ at a defined time $(\mathrm{t})$. This will enable to establish whether the possible engine operation $\left(\mathrm{D}_{\mathrm{M}}\right)$ for the given conditions is at least equal to przemiany energii, zatem działanie (D), w takim rozumieniu, jest wielkością wyrażającą energię (E) wydatkowaną w czasie (t) i z tego powodu może być określane wzorem (2).

Działanie (2) określa więc energię wydatkowaną w czasie, w którym ta energia została zużyta. W przypadku uwzględnienia zużycia silnika, działanie jest równoważne spadkowi (zmniejszeniu) energii w czasie, w którym było ono realizowane $[4,8,11]$. Energia zaś może być ujawniona tylko wtedy, gdy będzie przetworzona w formie pracy bądź ciepła $[6,8,13,14]$. Dotyczy to działania także innych urządzeń energetycznych, jak silników o zapłonie iskrowym, turbinowych silników spalinowych i innych [2, 13, 14].

$\mathrm{W}$ przypadku dowolnego silnika o zapłonie samoczynnym energia użyteczna $\left(E_{e}\right)$ wytwarzana przez silnik o określonej mocy użytecznej $\left(\mathrm{N}_{\mathrm{e}}\right.$ ), w ściśle określonych warunkach, może być uważana za miarę jego zdolności do wykonania pracy $\mathrm{L}_{\mathrm{e}}$ w określonym czasie t. Wobec tego praca ta, jako forma przemiany energii generowanej przez silnik, może być określona z wzoru (3) [13] wtedy, gdy: $\mathrm{M}_{\mathrm{o}}=$ idem oraz gdy $\mathrm{n}=\mathrm{idem}$.

Gdy $\mathrm{M}_{\mathrm{o}} \neq=$ idem oraz gdy $\mathrm{n} \neq$ idem praca może być przedstawiona $\mathrm{w}$ formie zależności (4).

W praktyce eksploatacyjnej silników o zapłonie samoczynnym stosowanych do napędu dowolnego statku (tzw. silników głównych) szczególnie istotne jest to, jak długo praca $\mathrm{L}_{\mathrm{e}}$ może być wyzwalana na potrzeby napędu głównego danego statku. Dotyczy to zwłaszcza statku, którego układ napędowy jest wyposażony w jeden taki silnik. W takim przypadku, gdy w wyniku zużycia silnik główny nie może być obciążony wymaganą mocą użyteczną $\left(\mathrm{N}_{\mathrm{e}}\right) \mathrm{w}$ czasie $\mathrm{t}$, nie może on w tym czasie wykonać wymaganej pracy $\mathrm{L}_{\mathrm{e}}$, aby zapewnić wytworzenie wymaganej siły naporu $(\mathrm{T})$ przez śrubę napędową statku. Wskutek tego wychylenie steru statku nawet o wartość maksymalną nie wystarczy do wytworzenia sily (S) wystarczającej do skompensowania wpływu działania wiatru i falowania morza. W rezultacie statek (każdy) traci najpierw sterowność (stateczność kursową) i nie może poruszać się w pożądanym kierunku, a następnie stateczność poprzeczną. Wtedy przy pojawieniu się wiatru baksztagowego i fali nadążającej w czasie znacznego falowania morza podczas sztormu, z reguły dochodzi do wywrócenia się bądź do zepchnięcia statku na skaliste wybrzeże lub piaszczystą mieliznę, co przeważnie kończy się katastrofą [9].

Z przedstawionych rozważań wynika, że sensowne jest analizowanie nie tylko mocy $\mathrm{N}_{\mathrm{e}}$ silników o zapłonie samoczynnym, wyzwalanych $w$ ich przestrzeniach roboczych i tym samym pracy $\mathrm{L}_{\mathrm{e}}$, ale także działania (D) tego rodzaju silników, rozumianego w tym przypadku jako przetwarzanie energii w tych przestrzeniach prowadzącego do uzyskania wymaganej pracy użytecznej $\left(\mathrm{L}_{\mathrm{e}}\right) \mathrm{w}$ określonym czasie $(\mathrm{t})$. Umożliwi to ustalenie, czy działanie silnika możliwe $\left(\mathrm{D}_{\mathrm{M}}\right)$, w danych warunkach, jest co najmniej równe działaniu wymaganemu $\left(\mathrm{D}_{\mathrm{w}}\right)$, niezbędnemu do wykonania określonego zadania $Z$.

\section{Dzialania silnika o zapłonie samoczynnym jako przetwarzanie energii $w$ formie ciepla i pracy}

Działanie silników polega na przetwarzaniu i przenoszeniu doprowadzonej energii. W przypadku silników spalinowych 
the demanded operation $\left(\mathrm{D}_{\mathrm{w}}\right)$ being indispensable to perform a defined task Z.

\section{Diesel engine operation as energy conversion in the form of heat and work}

The operation of engines consists in converting and transferring the supplied energy. In the case of combustion piston engines, first the chemical energy contained in the fuel-air mixture, generated in the workspaces, is converted into thermal energy and then the thermal energy - into mechanical energy (Fig. 1).

The interpretation of energy conversions presented in Fig. 1 considers the heat as a form of transformation of chemical energy contained in the fuel-air mixture into thermal energy and the work - as a form of transformation of thermal energy into mechanical energy [14].

It is obvious that the energy conversion in the form of heat in the workspaces of each diesel engine can proceed at a different time. In practice it is essential to make the performance of the work as high as possible or as quick as possible in a defined time. Additionally, it is important in practice to have the heat released from combustion to the highest possible extent and the heat lost in accordance with the second law of thermodynamics - as little as possible. If the most desired energy conversion cannot be obtained the engine is considered to work incorrectly and to be in the state of partial usability $[7,12,14]$.

In the case of diesel engines, conversion of chemical energy (fuel-air mixture burnt in the combustion chamber) into thermal energy and then into mechanical energy, generates torque $\left(\mathrm{M}_{\mathrm{o}}\right)$ of a crankshaft at a defined speed (n) of each engine $[12,13]$. Thus, the operation of engine, interpreted as energy conversion in the form of usable work Le expressed with the formula (4) can be defined by the equation as follows:

$$
D_{L_{e}}=\int_{0}^{t} L_{e}(\tau) d \tau=2 \pi \int_{0}^{t} n(\tau) M_{o}(\tau) \tau d \tau
$$

Engine operation connected with energy conversion in the form of work like compression of fresh charge, expansion of combustion gases in a cylinder, etc. can be considered in a similar way.

The determining of engine operation consisting in a conversion of chemical energy $\left(\mathrm{E}_{\mathrm{ch}}\right)$-contained in the fuel-air mixture generated in the engine combustion chamber-into thermal energy $\left(E_{c}\right)$ is equally important. Such an operation (Fig. 1) when conversion of this kind of energy proceeds in the form of heat $(\mathrm{Q})$ can be defined by the formula tłokowych następuje zamiana najpierw energii chemicznej zawartej w mieszaninie paliwowo-powietrznej, wytworzonej w komorach spalania, na energię cieplną a następnie zamiana tej energii cieplnej - na mechaniczną (rys. 1).

$\mathrm{W}$ interpretacji przemian energii przedstawionych na rys. 1 uwzględniono, że ciepło jest formą przemiany energii chemicznej mieszaniny paliwowo-powietrznej w energię cieplną, a praca - formą przemiany energii cieplnej w mechaniczną [14].
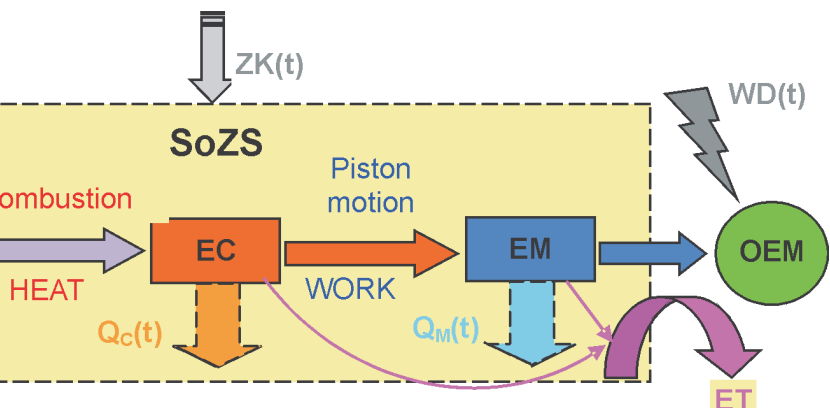

ET

作 engine operation, SoZS - diesel engine, OEM - mechanical energy receiver (e.g. ship propeller, genressor, pump), WD(t) - operating conditions OEM, $\mathrm{Q}_{C}(\mathrm{t})$ - thermal load in time $\mathrm{t}, \mathrm{Q}_{\mathrm{M}}(\mathrm{t})$ - mechanical load in time t, ET - losses of heat and mechanical energy [8]

Rys. 1. Przykładowy schemat przekształcenia energii w silniku o zapłonie samoczynnym: ST $(t)$ - sterowanie silnikiem, ECh - energia chemiczna, EC-energia cieplna, EM-energia mechamechanicznej (np. śruba napędowa statku, prąnica, sprężarka, pompa), WD(t) - warunki obciażenie cieplne $w$ chwili $t, Q_{M}(t)$ - obciążenie mechaniczne $w$ chwili $t$, ET-energia strat cieplnych i mechanicznych [8]

Jest oczywiste, że zachodząca $\mathrm{w}$ przestrzeniach roboczych każdego silnika spalinowego przemiana energii w formie ciepła bądź pracy może zachodzić w różnym czasie. $\mathrm{W}$ praktyce istotne jest, aby praca wykonana w określonym czasie była możliwie największa, albo aby dana praca była wykonana możliwie najszybciej; istotne jest także, aby podczas spalania wyzwalane było możliwie największe ciepło, zaś ciepło tracone zgodnie $\mathrm{z}$ drugą zasadą termodynamiki - możliwie najmniejsze. Jeśli nie można uzyskać takiej przemiany energii, która jest najkorzystniejsza, uznaje się, że silnik działa niewłaściwie i przyjmuje się, że jest on wtedy w stanie częściowej zdatności [7, 12, 14].

Odnośnie do silników o zapłonie samoczynnym, przetwarzanie energii chemicznej (zawartej w wytworzonej w komorach spalania mieszaninie paliwowo-powietrznej) na energię cieplną a następnie mechaniczną, umożliwia wytworzenie momentu obrotowego $\left(\mathrm{M}_{\mathrm{o}}\right)$ wału korbowego przy określonej prędkości obrotowej (n) każdego silnika [12,13]. Zatem działanie silnika interpretowane jako przetwarzanie energii w formie pracy użytecznej $L_{e}$ wyrażone wzorem (4) może być wyrażone wzorem (5).

Podobnie może być rozważane działanie silnika związane z przetwarzaniem energii $\mathrm{w}$ formie pracy sprężania świeżego ładunku, rozprężania spalin w cylindrze itp.

Równie ważne jest określenie działania silników polegające na przemianie energii chemicznej $\left(\mathrm{E}_{\mathrm{ch}}\right)$ zawartej w 


$$
\mathrm{D}_{\mathrm{Q}}=\int_{0}^{\mathrm{t}} \mathrm{Q}(\tau) \mathrm{d} \tau
$$

Because the operation of this kind of engines consists in converting energy $\mathrm{E}$ in the form of work and heat, it can be generally interpreted as follows

$$
\mathrm{D}=\int_{0}^{\mathrm{t}} \mathrm{E}(\tau) \mathrm{d} \tau
$$

where: D - engine operation, E - converted (obtained) energy enabling realization of a task $\mathrm{Z}, \mathrm{t}-$ time of $\mathrm{E}$ energy conversion (consumption).

Engines during operation are under heat and mechanical loads which are the reason for growing engine wear and energy losses (Fig. 1). Usability of particular combustion engines can be obtained after making value calculations of their operations (7) which are, in the interpretation here proposed, equaled to physical quantities with the measurement unit: ,joule-second". Apparently, the functional dependence of energy on time $-E=f(t)$ must be known in order to determine the field of operation (D). Because $D=f(E, t)$ the operation of machines can be presented in the coordinate system ,D-E-t" [5-7].

Such understood operation defined by formula (7) can be presented in the coordinate system „E-t" in the form of graph which I propose to call graph of operation. An example of such an graph of operation for the range of the energy transformation from $E_{1}$ into $E_{2}$ for any selected time $t_{0}=0$ and $t$ is presented in Fig. 2.

The graph of engine operation presented in Fig. 2 demonstrates realizations of the stochastic process in the form of dependences $\{\mathrm{E}(\mathrm{t}) ; \mathrm{t} \geq 0\}$ where energy $\mathrm{E}$ is a random variable. The process is characterized by expected value $\mathrm{E}[\mathrm{E}(\mathrm{t})]$ and the standard deviation $\sigma[\mathrm{E}(\mathrm{t})]$ for the energy $\mathrm{E}$. This approach follows from the fact that the analysis and the resulting assessment of combustion engine operation can be presented in a probabilistic aspect with the application of the theory of stochastic processes.

A stochastic process is a random function of which the parameter is time t. The time is not a random variable $[1,3]$. This approach towards the issue of expressing the diesel engine operation as a value, results from the necessity of getting information as to what the operation can be in the interval defined by two arbitrary moments, e.g. in the interval $\left[\mathrm{t}_{0}, \mathrm{t}_{\mathrm{n}}\right]$. In this case, analyzing the operation of each combustion engine, each time $t$ from the considered time interval $\left[\mathrm{t}_{0}, \mathrm{t}_{\mathrm{n}}\right]$ can be assigned by a state called momentary state of the process, which is a random variable $\mathrm{X}_{t}$ with expected value $E\left(X_{t}\right)$ and variation $D^{2}\left(X_{t}\right)$ dependent from the $t$ value. For the considerations the variable can be energy (E) or forms of its conversion-work $\left(\mathrm{L}_{\mathrm{e}}\right)$ or heat $(\mathrm{Q})$. Thus, the stochastic process (a random function) is a set of random variables $X_{t}$ for $\mathrm{t} \in\left[\mathrm{t}_{0}, \mathrm{t}_{\mathrm{n}}\right]$, so for $\mathrm{t}_{0} \leq \mathrm{t} \leq \mathrm{t}_{\mathrm{n}}$. The function expected value $E[X(t)]$ and variation $D^{2}[X(t)]$ are defined by the sets of expected values $E\left(X_{t}\right)$ and variations $D^{2}\left(X_{t}\right)$ for $t_{0} \leq t \leq t_{n}$. mieszaninie paliwowo-powietrznej wytwarzanej w komorach spalania silnika na energię cieplną $\left(\mathrm{E}_{\mathrm{c}}\right)$. Takie działanie (rys. 1), w którym następuje przemiana tego rodzaju energii w formie ciepła (Q) może być określone zależnością (6).

Ze względu na to, że działanie tego rodzaju silników polega na przetwarzaniu energii $\mathrm{E} w$ formie pracy i ciepła wobec tego, w ujęciu ogólnym, można je interpretować jako (7), gdzie: D - działanie silnika, E - energia przetworzona (uzyskana), umożliwiająca realizację jakiegoś zadania $\mathrm{Z}$, $\mathrm{t}$ - czas przetwarzania (zużywania) energii $\mathrm{E}$.

Silniki podczas działania są obciążone cieplnie i mechanicznie, co jest przyczyną narastania zużycia silników i związanych z nim strat energii (rys. 1). O przydatności poszczególnych silników spalinowych można wnioskować po dokonaniu obliczenia wartości ich działania (7), które w zaproponowanej interpretacji zostało przyrównane do wielkości fizycznej o jednostce miary nazywanej dżulosekunda. Aby wyznaczyć pole działania (D), trzeba znać zależność funkcyjną energii od czasu, czyli $E=f(t)$. Ze względu na to, że $\mathrm{D}=\mathrm{f}(\mathrm{E}, \mathrm{t})$, wobec tego działanie urządzeń można także przedstawić w układzie współrzędnych „D-E-t” [5, 6, 7].

Tak rozumiane działanie, określone zależnością (7), może być przedstawione w układzie współrzędnych „E-t”, a więc w formie wykresu, nazwanego wykresem działania. Przykład takiego wykresu działania, w zakresie zmian energii od $\mathrm{E}_{1}$ do $\mathrm{E}_{2}$ dla dowolnie wybranych chwil $\mathrm{t}_{0}=0$ oraz $\mathrm{t}$ przedstawiono na rys. 2 .

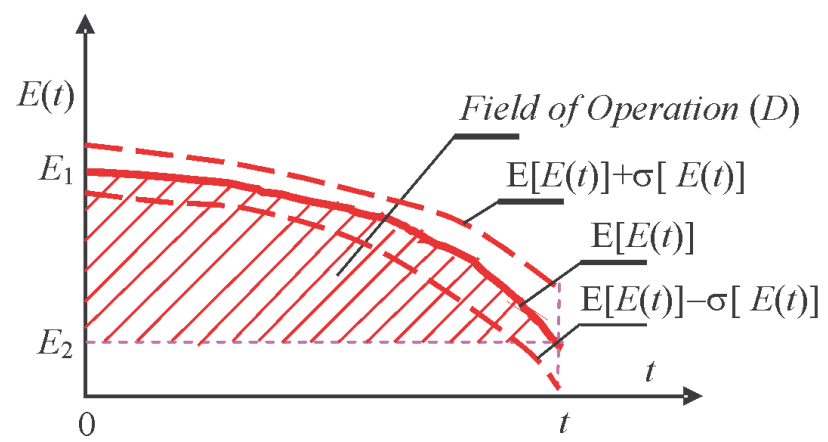

Fig. 2. An example graph of engine operation: $\mathrm{E}$ - energy, $\mathrm{E}_{1}$ - energy in the moment $\left(\mathrm{t}_{0}=0\right)$ of starting the task, $\mathrm{E}_{2}$ - energy in the moment $(\mathrm{t})$ of task completion, $\mathrm{t}$ - time, $\mathrm{E}[\mathrm{E}(\mathrm{t})]$ - expected value $\mathrm{E}, \sigma[\mathrm{E}(\mathrm{t})]-$ standard deviation for $\mathrm{E}$

Rys. 2. Przykład wykresu działania silnika: E-energia, $E_{1}$ - energia $w$ chwili $\left(t_{0}=0\right)$ rozpoczęcia zadania, $E_{2}$ - energia $w$ chwili $(t)$ zakończenia zadania, $t-c z a s, E[E(t)]-$ wartość oczekiwana $E$, $\sigma[E(t)]$-odchylenie standardowe $E$

Przykład wykresu działania silnika przedstawiony na rys. 2 obrazuje realizacje procesu stochastycznego w formie zależności $\{\mathrm{E}(\mathrm{t}) ; \mathrm{t} \geq 0\}$, gdzie energia $\mathrm{E}$ jest zmienną losową. Proces ten charakteryzuje wartość oczekiwana $\mathrm{E}[\mathrm{E}(\mathrm{t})]$ oraz odchylenie standardowe $\sigma[\mathrm{E}(\mathrm{t})]$ energii $\mathrm{E}$. Takie podejście wynika z tego, że analiza i wynikająca z niej ocena działania silników spalinowych może być przedstawiona $\mathrm{w}$ ujęciu probabilistycznym z zastosowaniem teorii procesów stochastycznych.

Proces stochastyczny jest funkcją losową, której parametrem jest czas t. Czas ten nie jest zmienną losową $[1,3]$. 
It should be pointed here that expected value $\mathrm{E}\left(\mathrm{X}_{\mathrm{t}}\right)$ and the variation $D^{2}\left(X_{t}\right)$ of the random function $\{X(t): t \geq 0\}$ depend on time $t$ because the values $\mathrm{E}\left(\mathrm{X}_{\mathrm{t}}\right)$ and $\mathrm{D}^{2}\left(\mathrm{X}_{\mathrm{t}}\right)$ can be different for different $t$ values. They are not, however, random functions $\mathrm{X}(\mathrm{t})$ because $\mathrm{E}\left(\mathrm{X}_{t}\right)$ and $\mathrm{D}^{2}\left(\mathrm{X}_{\mathrm{t}}\right)$ are not random variables but the constants for the given $t$ value and the given set of realizations of the random variable $X_{t}[3]$.

An example of dependences of $\mathrm{E}\left(\mathrm{X}_{t}\right)$ and $\mathrm{D}^{2}\left(\mathrm{X}_{t}\right)$ on time $t$ is shown in Fig. 2, at the assumption that random variable $\mathrm{X}$ is energy $\mathrm{E}$ supplied by a combustion engine to a receiver of the energy. In this Fig. the $\sigma[\mathrm{E}(\mathrm{t})]$ quantity is a standard deviation of the random variable $\mathrm{E}$. This quantity is a square root of the variation $\mathrm{D}^{2}\left(\mathrm{E}_{\mathrm{t}}\right)$.

In this case, to define the operation D from formula (7) the integral calculus can be applied because the integral defined by the formula is a definite Riemann integral with the integration range $[0, t]$ and the integrand $E(\tau)$. Because the function $\mathrm{E}(\tau)$ is continuous for the examined example range $[0, t]$, it can be stated in compliance with the second fundamental theorem of integral calculus (Newton-Leibniz Theorem) that [16]

$$
\int_{0}^{\mathrm{t}} \mathrm{E}(\tau) \mathrm{d} \tau=\mathrm{D}(\mathrm{t})-\mathrm{D}(0)=\left.\mathrm{D}(\tau)\right|_{0} ^{\mathrm{t}}
$$

whereas: $\left.\mathrm{D}(\tau)\right|_{0} ^{\mathrm{t}}=\mathrm{D}(\mathrm{t})-\mathrm{D}(0)$

The application of the Newton-Leibniz Theorem is necessary here because it enables to effectively determine a definite integral for the continuous functions if a determination of any primitive for the functions is possible.

Generally, the functional dependence $E=f(t)$ is compound. In the case when the internal function derivative for such a function is constant it is possible to define a definite integral of function $\mathrm{f}(\mathrm{t})$ [16] applying the integration by substitution. Not always, however, a compound function describing the dependence of energy from time can be defined by elementary functions. Then, defining a definite integral from the NewtonLeibniz formula is troublesome and sometimes even impossible. The trouble is that the determination of a primitive is connected with the necessity to make difficult transformations. In such cases, just like when the integrand is determined in the form of a table, an approximate value of the engine operation can be calculated as a definite integral value, applying the Method of Trapezoids or the Simpson's method [16]. It should be taken into account that the application of the Simpson's method enables getting more precise results of integration than in the case of application of the Method of Trapezoids.

The estimation of expected value $\mathrm{E}[\mathrm{E}(\mathrm{t})]$ for each value of time $t$ requires an application of statistical inference (point or interval estimation $[1,3])$.

From the presented interpretation of combustion engine operation (Fig. 1) follows that the operation consists in converting and transferring the supplied energy in the form of work (L) and heat (Q), whereas both of the forms of energy conversions can be presented as the fields $[13,14]$ :

- in the Clapeyron diagram (diagram of work) when analyzing work L
Takie podejście do zagadnienia wartościowania działania silników o zapłonie samoczynnym wynika z konieczności uzyskania informacji o tym, jakie może być ich działanie w przedziale określonym przez dowolne dwie chwile, np. w przedziale $\left[\mathrm{t}_{0}, \mathrm{t}_{\mathrm{n}}\right]$. W tym przypadku, dla każdego czasu $\mathrm{t} \mathrm{w}$ rozpatrywanym przedziale czasu $\left[\mathrm{t}_{0}, \mathrm{t}_{\mathrm{n}}\right]$ można, analizując działanie każdego silnika spalinowego, przyporządkować stan, nazywany stanem chwilowym procesu, który jest zmienną losową $X_{t}$ o wartości oczekiwanej $E\left(X_{t}\right)$ i wariancji $\mathrm{D}^{2}\left(\mathrm{X}_{\mathrm{t}}\right)$, zależnych od wartości t. W tych rozważaniach zmienną tą może być energia (E) lub formy jej przemiany, czyli praca $\left(\mathrm{L}_{\mathrm{e}}\right)$ bądź ciepło $(\mathrm{Q})$. Zatem proces stochastyczny (funkcja losowa) jest zbiorem zmiennych losowych $\mathrm{X}_{\mathrm{t}}$ dla $\mathrm{t} \in\left[\mathrm{t}_{0}, \mathrm{t}_{\mathrm{n}}\right]$, czyli dla $\mathrm{t}_{0} \leq \mathrm{t} \leq \mathrm{t}_{\mathrm{n}}$. Jej wartość oczekiwana $\mathrm{E}[\mathrm{X}(\mathrm{t})]$ i wariancja $\mathrm{D}^{2}[\mathrm{X}(\mathrm{t})]$ są wyznaczone przez zbiory wartości oczekiwanych $\mathrm{E}\left(\mathrm{X}_{\mathrm{t}}\right)$ i wariancji $\mathrm{D}^{2}\left(\mathrm{X}_{\mathrm{t}}\right)$ dla $\mathrm{t}_{0} \leq \mathrm{t} \leq \mathrm{t}_{\mathrm{n}}$. Należy przy tym zaznaczyć, że wartość oczekiwana $E\left(X_{t}\right)$ i wariancja $D^{2}\left(X_{t}\right)$ funkcji losowej $\{X(t): t \geq 0\}$ zależą od czasu $t$, ponieważ wartości $\mathrm{E}\left(\mathrm{X}_{\mathrm{t}}\right)$ i $\mathrm{D}^{2}\left(\mathrm{X}_{\mathrm{t}}\right)$ mogą być różne dla różnych wartości t. Jednak nie są to funkcje losowe $\mathrm{X}(\mathrm{t})$, ponieważ $\mathrm{E}\left(\mathrm{X}_{t}\right)$ oraz $\mathrm{D}^{2}\left(\mathrm{X}_{\mathrm{t}}\right)$ nie są zmiennymi losowymi, lecz wielkościami stałymi dla danej wartości t i danego zbioru realizacji zmiennej losowej $\mathrm{X}_{\mathrm{t}}[3]$.

Przykład zależności $\mathrm{E}\left(\mathrm{X}_{\mathrm{t}}\right)$ oraz $\mathrm{D}^{2}\left(\mathrm{X}_{\mathrm{t}}\right)$ od czasu t przedstawiono na rys. 2 przy założeniu, że zmienną losową $\mathrm{X}$ będzie energia $\mathrm{E}$ dostarczana przez silnik spalinowy do odbiornika tej energii. Na rysunku tym wielkość $\sigma[\mathrm{E}(\mathrm{t})]$ jest odchyleniem standardowym zmiennej losowej E. Wielkość ta jest pierwiastkiem kwadratowym wariancji $\mathrm{D}^{2}\left(\mathrm{E}_{\mathrm{t}}\right)$.

W takim przypadku do wyznaczenia działania $\mathrm{D}$ ze wzoru (7) można zastosować rachunek całkowy, ponieważ całka określona tym wzorem jest całką Riemanna o przedziale całkowania $[0, t]$ i funkcji podcałkowej $\mathrm{E}(\tau)$. Ze względu na to, że funkcja $\mathrm{E}(\tau)$ jest ciągła w rozpatrywanym przykładowo przedziale $[0, \mathrm{t}]$, można zgodnie $\mathrm{z}$ drugim głównym twierdzeniem rachunku całkowego (twierdzeniem Newtona-Leibniza) napisać równanie (8) [16], przy czym $\left.\mathrm{D}(\tau)\right|_{0} ^{\mathrm{t}}=\mathrm{D}(\mathrm{t})-\mathrm{D}(0)$.

Zastosowanie twierdzenia Newtona-Leibniza jest tu konieczne, ponieważ umożliwia efektywne wyznaczenie całki oznaczonej funkcji ciągłych, jeśli możliwe jest określenie jakiejkolwiek funkcji pierwotnej tych funkcji.

Na ogół zależność funkcyjna $E$ = f(t) jest złożona. Gdy dla takiej funkcji pochodna funkcji wewnętrznej jest funkcją stałą, można, stosując całkowanie przez podstawianie, określić całkę oznaczoną funkcji f(t) [16]. Nie zawsze jednak funkcja złożona określająca zależność energii od czasu jest możliwa do określenia przez funkcje elementarne. Wtedy określenie całki oznaczonej ze wzoru Newtona-Leibniza jest kłopotliwe, a niekiedy nawet niemożliwe. Problem polega na tym, że wyznaczanie funkcji pierwotnej związane jest wtedy z koniecznością dokonywania trudnych przekształceń. W takich przypadkach, podobnie jak wtedy, gdy funkcja podcałkowa jest określona w formie tabeli, można obliczyć przybliżoną wartość działania silnika, jako wartość całki oznaczonej, stosując metodę trapezów lub metodę Simpsona [16]. Należy mieć przy tym na uwadze to, że zastosowanie 
- in the Belpaire diagram (diagram of heat) when analyzing heat $\mathrm{Q}$.

Taking into account the energy conversions in their realization time $t$ not only the field of work can be demonstrated using the " $\mathrm{p}-\mathrm{V}-\mathrm{t}$ " system, but also the field of engine operation. For instance, Fig. 3 and 4 show the technical work of extension of combustion gases in any engine cylinder from thermodynamic state 1 to state 2 as well as the field of engine operation during the conversion process.

Figure 3 reflects the case when time $t$ of the expansion process of combustion gases in any engine cylinder is insignificant and can be regarded as close to zero $(\mathrm{t} \approx 0)$. Whereas, Fig. 4 reflects the case when time $t$ of the expansion process of combustion gases in any engine cylinder is significant and hence must be regarded as greater than zero $(t>0)$.

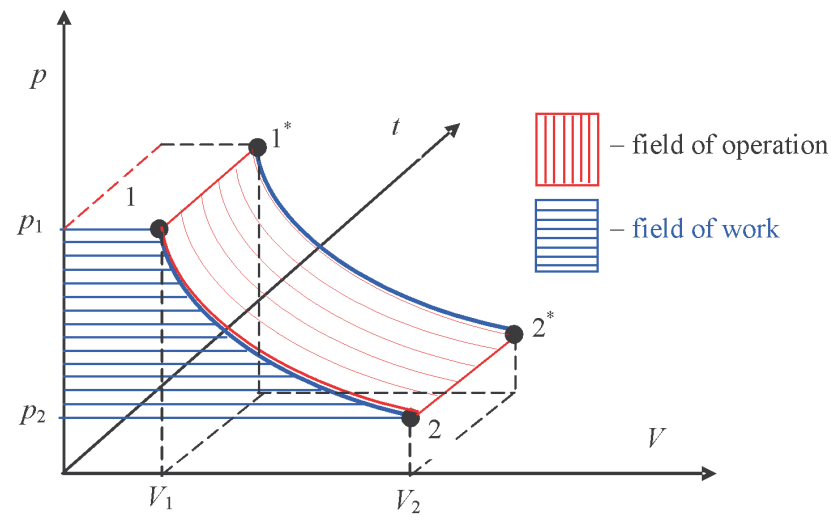

Fig. 3. Graph of technical work and operation of a combustion engine (performed during the expansion of combustion gases in any engine cylinder) in the , $\mathrm{p}-\mathrm{V}-\mathrm{t}$ ” system, when the extension time is insignificant: $\mathrm{p}$ - pressure in the workspace, $\mathrm{V}$ - volume, $\mathrm{t}$ - time, 1 - initial state, 2 - end state, $p_{1}$ - initial pressure, $p_{2}$ - end pressure, $V_{1}$ - initial volume, $\mathrm{V}_{2}$ - end volume, $\mathrm{t}_{11^{*}}=\mathrm{t}_{22^{*}}$ - time of engine operation

Rys. 3. Graficzna interpretacja pracy technicznej i działania silnika spalinowego (wykonanej podczas rozprężania spalin $w$ dowolnym cylindrze silnika) w uktadzie , $p-V-t$ ", gdy czas rozprężania nie jest istotny: $p$-ciśnienie w przestrzeni roboczej, $V$-objętość, $t$-czas, 1 -stan początkowy, 2 - stan końcowy, $p_{1}$ - ciśnienie początkowe, $p_{2}$ - ciśnienie końcowe, $V_{1}$-objętość początkowa, $V_{2}$-objętość końcowa, $t_{11^{*}}=t_{22^{*}}-$ czas, $w$ którym działa silnik

A field of any other work (e.g. air compression in a cylinder, indicated work, usable work, etc.) can be presented in a similar way as well as a field of engine operation which follows from this work.

In the introduction hereto it has been indicated that the operation in the interpretation presented herein will enable a determination whether the possible engine operation $\left(D_{M}\right)$ for the given conditions is at least equal to the demanded operation $\left(\mathrm{D}_{\mathrm{W}}\right)$ being indispensable to perform the task $(\mathrm{Z})$. That means the operation in the presented interpretation is of essential practical significance.

\section{Practical significance of engine operation with the value interpretation}

Task for which a combustion engine has been designed and manufactured can be performed only when the following inequality is satisfied metody Simpsona umożliwia uzyskanie dokładniejszych wyników całkowania niż w przypadku zastosowania metody trapezów.

Oszacowanie wartości oczekiwanej $E[E(t)]$ dla każdej wartości czasu t wymaga zastosowania wnioskowania statystycznego, które polega na zastosowaniu estymacji punktowej bądź przedziałowej [1,3].

Z przestawionej interpretacji działania silników spalinowych wynika (rys. 1), że działanie to polega na przetwarzaniu i przenoszeniu doprowadzonej energii w formie pracy (L) i ciepła (Q), przy czym obie te formy przemiany energii mogą być zobrazowane w formie pól $[13,14]$ :

- w układzie Clapeyrona (układzie pracy) w przypadku analizy pracy $\mathrm{L}$

- w układzie Belpaire’a (układzie ciepła) w przypadku analizy ciepła $\mathrm{Q}$.

Uwzględniając te przemiany energii w czasie $\mathrm{t}$ ich realizacji, można, korzystając z układu ,p-V-t”, zobrazować nie tylko pole pracy, lecz także pole działania silnika. Przykładowo na rys. 3 i 4 przedstawiono pracę techniczną rozprężania spalin $\mathrm{w}$ dowolnym cylindrze silnika od stanu termodynamicznego 1 do stanu 2 oraz pole działania silnika podczas realizacji tej przemiany.

Rysunek 3 odzwierciedla przypadek, gdy czas t, w którym realizowany jest proces rozprężania spalin w dowolnym cylindrze silnika, jest mało istotny i może być uznany za bliski zeru $(\mathrm{t} \approx 0)$. Natomiast rysunek 4 odzwierciedla przypadek, gdy czas $t$, w którym realizowany jest proces rozprężania spalin w dowolnym cylindrze silnika, jest istotny i dlatego musi być uznany za większy od zera $(\mathrm{t}>0)$.

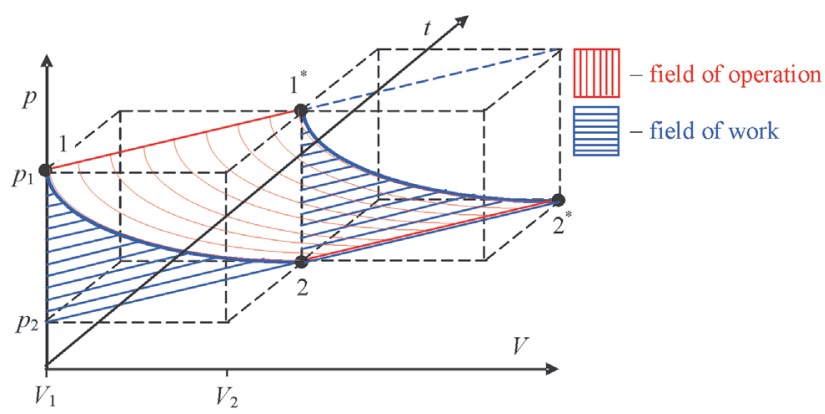

Fig. 4. Graph of technical work and operation of a combustion engine in the ,p-V-t" system, when the extension time is significant: $\mathrm{p}$ - pressure in the workspace, $\mathrm{V}$ - volume, $\mathrm{t}$ - time, 1 - initial state, 2 - end state, $\mathrm{p}_{1}$ - initial pressure, $\mathrm{p}_{2}$ - end pressure, $\mathrm{V}_{1}$ - initial volume, $\mathrm{V}_{2}-$ end volume, $\mathrm{t}_{12}=\mathrm{t}_{1^{*} 2^{*}}-$ time of technical work, $\mathrm{t}_{11^{*}}=\mathrm{t}_{22^{*}}-$ time of engine operation

Rys. 4. Graficzna interpretacja pracy technicznej i działania silnika spalinowego w uktadzie ,"p-V-t”, gdy czas rozprężania jest istotny: $p$-ciśnienie w przestrzeni roboczej, $V$-objętość, $t$-czas, 1 -stan poczatkowy, 2 -stan końcowy, $p_{1}$-ciśnienie poczatkowe, $p_{2}$-ciśnienie końcowe, $V_{1}$-objętość początkowa, $V_{2}$-objętość końcowa, $t_{12}=t_{1 * 2 *}-c z a s, w$ którym wykonywana jest praca techniczna $t_{1 I^{*}}=t_{22^{*}}-$ czas, $w$ którym działa silnik

Podobnie można przedstawić pole każdej innej pracy (np. sprężania powietrza w cylindrze, indykowanej, użytecznej itd.) i pole działania silnika, które wynika z tej pracy.

We wstępie tego artykułu zasygnalizowano, że działanie o przedstawionej tu interpretacji umożliwi ustalenie, czy 
so when:

$$
\mathrm{D}_{\mathrm{M}} \geq \mathrm{D}_{\mathrm{W}}
$$

$$
t_{M} \geq t_{w} \text {, when at the same time } E_{M} \geq E_{w}
$$

where: $\mathrm{t}_{\mathrm{M}}$ - possible operating time, $\mathrm{t}_{\mathrm{W}}$ - demanded operating time, $\mathrm{E}_{\mathrm{M}}$ - energy that can be converted by engine, $\mathrm{E}_{\mathrm{W}}-\mathrm{de}$ manded (desired) energy to perform the task $Z$ (energy that must be converted to enable a performance of the task).

That means that when analyzing the energetic properties of combustion engines (not only diesel ones) the ability of this type of engines (as well as other energetic systems) to work can be considered in the following alternatives:

$\mathrm{t}_{\mathrm{M}}=\mathrm{t}_{\mathrm{w}}$ when at the same time $\mathrm{E}_{\mathrm{M}}=\mathrm{E}_{\mathrm{W}}$

$\mathrm{t}_{\mathrm{M}}=\mathrm{t}_{\mathrm{w}}$ when at the same time $\mathrm{E}_{\mathrm{M}}>\mathrm{E}_{\mathrm{W}}$

$t_{M}>t_{w}$ when at the same time $E_{M}=E_{W}$

$t_{M}>t_{w}$ when at the same time $E_{M}>E_{W}$

In the case when the inequality emerges:

$$
\mathrm{D}_{\mathrm{M}}<\mathrm{D}_{\mathrm{W}}
$$

the engine (as well as any other energetic system) is damaged and is not able to perform the task $\mathrm{Z}$.

The inequalities (9), (10) and (11) are also true when dissipation of energy converted in the form of heat is considered. In such a case the heat is carried away from the engine and therefore (in accordance with the interpretation used in thermodynamics) gets a negative value.

\section{Description of engine operation in case of applying a model in the form of a homogenous Poisson process}

Application of a model of changes in the operation of a combustion engine, in the form of a homogenous Poisson process enables a description of decreasing the energy $\mathrm{E}$ converted by the engine over time $t$ by an elementary portion (quantum) e which can be recorded by a measuring device with the constant intensity $\lambda>0$ ( $\lambda=$ idem). Then, the course of the decreasing energy $\mathrm{E}$ can be expressed as follows $[1,4,6,7]$ :

$$
E(t)=\left\{\begin{array}{l}
E_{\text {max }} \quad \text { dla } \quad t=0 \\
E_{\text {max }}-e \lambda t \pm e \sqrt{\lambda t} \quad \text { dla } \quad t>0
\end{array}\right.
$$

Graphic interpretation of the formula (12) is presented in Fig. 5 for $E_{i}(i=1, \ldots, 6)$.

Another possibility of description of the decreasing energy supplied by the engine to a receiver and simultaneously of deteriorating operation of the engine can be obtained when we apply an engine operation model as a semi-Markov process $[6,7,10]$. działanie silnika możliwe $\left(\mathrm{D}_{\mathrm{M}}\right)$ w danych warunkach jest co najmniej równe wymaganemu $\left(\mathrm{D}_{\mathrm{W}}\right)$, niezbędnemu do wykonania zadania $(Z)$. Oznacza to, że działanie w przedstawionej interpretacji ma istotne znaczenie praktyczne.

\section{Znaczenie praktyczne działania silnika o wartościującej interpretacji}

Zadanie, do którego wykonania silnik spalinowy przysposobiono w fazie projektowania i wytwarzania, może być zrealizowane tylko wtedy, gdy będzie spełniona nierówność (9), czyli, gdy: $\mathrm{t}_{\mathrm{M}} \geq \mathrm{t}_{\mathrm{w}}$, gdy jednocześnie $\mathrm{E}_{\mathrm{M}} \geq \mathrm{E}_{\mathrm{w}}$, gdzie: $\mathrm{t}_{\mathrm{M}}-$ czas działania możliwy, $\mathrm{t}_{\mathrm{w}}$ - czas działania wymagany, $\mathrm{E}_{\mathrm{M}}$ - energia, która może być przetworzona przez silnik, $\mathrm{E}_{\mathrm{W}}$ - energia wymagana (potrzebna) do wykonania zadania Z (energia, jaka musi być przetworzona, aby zadanie $\mathrm{Z}$ było wykonane).

Oznacza to, że analizując walory energetyczne silników spalinowych (nie tylko o zapłonie samoczynnym), można rozpatrywać zdatność do działania tego rodzaju silników (jak też innych urządzeń energetycznych) w wariantach równania (10).

Gdy zachodzi nierówność (11), silnik jest uszkodzony (podobnie jak każde inne urządzenie energetyczne) i nie może wykonać zadania $\mathrm{Z}$.

Nierówności (9), (10) i (11) są także prawdziwe, gdy rozpatrywane będzie rozpraszanie energii przetwarzanej $\mathrm{w}$ formie ciepła. Wtedy ciepło to będzie odprowadzone $\mathrm{z}$ silnika i wobec tego (zgodnie $\mathrm{z}$ interpretacją stosowaną w termodynamice) będzie ono miało wartość ujemną.

\section{Opis działania silnika w sytuacji zastosowania modelu w formie jednorodnego procesu Poissona}

Zastosowanie modelu zmian działania silnika spalinowego w formie jednorodnego procesu Poissona umożliwia opis zmniejszania energii E, przetwarzanej przez silnik, z upływem czasu t o elementarną porcję (kwant) e, która może

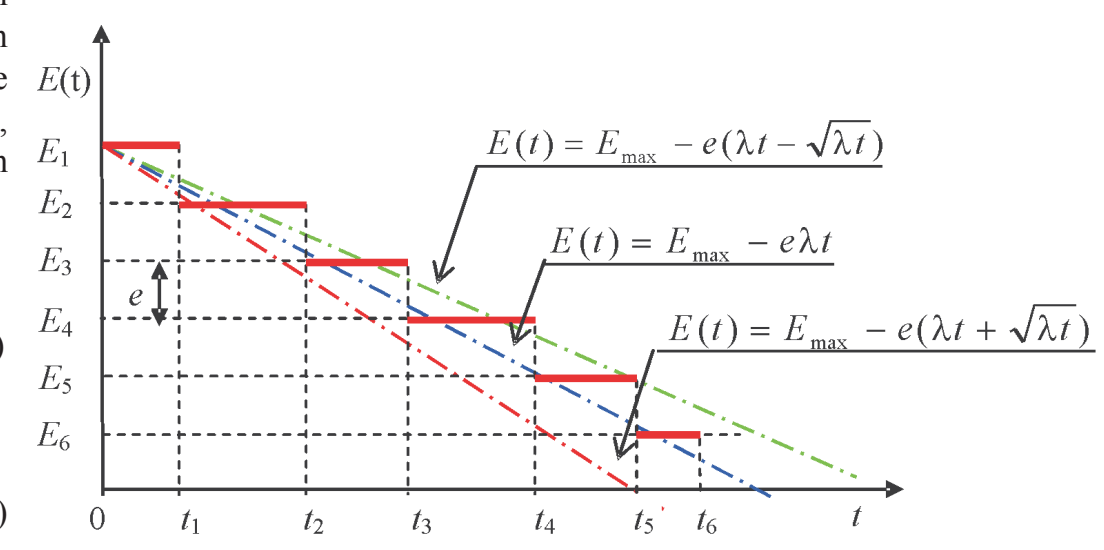

Fig. 5. Graphic interpretation of example realization of decreasing energy of engine:

$\mathrm{E}$ - energy, e - energy quantum by which the energy $\mathrm{E}$ is decreased and which can be recorded by a measuring device; $\lambda$ - intensity of occurrence of the quanta (e) by which the energy $E$ is decreased, recorded by a measuring device, $\mathrm{t}$ - time, $\mathrm{E}_{1}=\mathrm{E}_{\max }, \mathrm{E}_{6}=\mathrm{E}_{\min }$ [7]

Rys. 5. Graficzna interpretacja przykładowej realizacji zmniejszania energii silnika: E- energia, e - kwant energii, o który ulega zmniejszeniu energia E i który może być zarejestrowany przez urządzenie pomiarowe; $\lambda$ - intensywność pojawiania się zarejestrowanych przez urządzenie pomiarowe kwantów (e), o które zmniejszana jest energia $E$, $t$-czas, $E_{1}=E_{\max }, E_{6}=E_{\min }[7]$ 


\section{A description of engine operation in the case when we apply a model as a semi-Markov proc- ess}

In the case we apply a semi-Markov model to describe the deteriorating operation of any combustion engine, it can be considered a semi-Markov process $\{\mathrm{D}(\mathrm{t}): \mathrm{t} \geq 0\}$ with the set of states of the energy $E_{z}=\left\{E_{i} ; i=1,2, \ldots, k\right\}$ being supplied to a receiver and with the graph of state transitions presented in Fig. 6 [7].

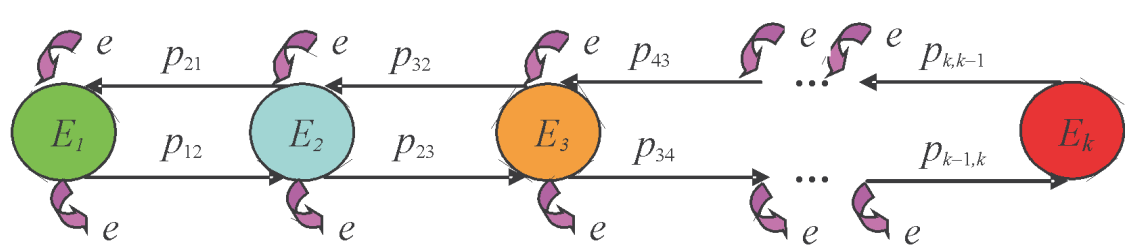

Fig. 6. Graph of state transitions of the process $\{D(t): t \geq 0\}: E_{i}(i=1,2, \ldots, k)-$ states of the process, increasing one by one in successively by quantum e, $p_{i j}(i, j=1,2, \ldots, k ; i \in j)$ - probability of state transitions [7]

Rys. 6. Graf zmian stanów procesu $\{D(t): t \geq 0\}: E_{i}(i=1,2, \ldots, k)$-stany procesu kolejno mniejsze o kwant e, $p_{i j}(i, j=1,2, \ldots, k ; i \in j)$-prawdopodobieństwa zmian stanów [7] być rejestrowana przez urządzenie pomiarowe $\mathrm{z}$ intensywnością stałą $\lambda>0(\lambda=$ idem $)$. Wtedy przebieg zmniejszania energii E można wyrazić wzorem (12) [1, 4, 6, 7].

Graficzna interpretacja zależności (12) przedstawiona jest na rys. 5 , dla $\mathrm{E}_{\mathrm{i}}(\mathrm{i}=1, \ldots, 6)$.

Inną możliwość opisu zmniejszania energii dostarczanej przez silnik do odbiornika, a tym samym pogarszania się jego działania, można uzyskać przy zastosowaniu modelu działania silnika w formie procesu semimarkowskiego $[6,7,10]$.

\section{Opis działania silnika przy zastosowaniu modelu $w$ formie procesu semimarkowskiego}

W przypadku zastosowania modelu semimarkowskiego do opisu pogarszania się działania dowolnego silnika spalinowego, można rozpatrywać proces semimarkowski $\{\mathrm{D}(\mathrm{t}): \mathrm{t} \geq 0\}$ o zbiorze stanów energii $\mathrm{E}_{\mathrm{z}}=\left\{\mathrm{E}_{\mathrm{i}} ; \mathrm{i}=1\right.$, $2, \ldots, \mathrm{k}\}$ dostarczanej do odbiornika $\mathrm{i}$ grafie zmian stanów przedstawionym na rys. 6 [7].

$\mathrm{W}$ modelu tym uwzględniono to,

The model takes into account the fact that operation of the engine deteriorates with wear. Then the states occur one by one in successively starting from state $\mathrm{E}_{1}$ which transits to $E_{2}$, then to $E_{3}$, and so on, and finally to $E_{k}$ which makes further operation of the engine impossible. The engine can go back from any occurred state $\mathrm{E}_{\mathrm{i}}(\mathrm{i}=2,3, \ldots, \mathrm{k})$ to any state $\mathrm{E}_{\mathrm{i}-1}$ if it undergoes a maintenance (technical service).

Probabilities of occurrence of the states $E_{j} ; i=1,2, \ldots, k$ considered in the graph (6) can be determined from the following dependences $[7,10]$ :

$$
P_{j}=\frac{\prod_{m=2}^{j} \frac{\left(1-q_{m-1}\right)}{q_{m}} E\left(T_{j}\right)}{E\left(T_{1}\right)+\sum_{j=2}^{k}\left[\prod_{m=2}^{j} \frac{\left(1-q_{m-1}\right)}{q_{m}}\right] E\left(T_{j}\right)}, j=2,3, \ldots k
$$

An example realization of the process of decreasing energy of engine is presented in Fig. 7.

\section{Conclusions}

The operation of combustion engines is understood as combustion engines generating energy $E$ at a defined time $t$. It has been equated to a physical quantity which can be expressed with a numerical value and the measurement unit called joule-second [joule $\times$ second]. Such understood operation deteriorates with a growing wear of this type of engine. This means that the operation value at a defined time decreases as a result of decreasing energy generated by the engine. It has been mentioned herein that in the case of application of the theory of stochastic processes to the analysis of the changes of such understood operation the integral calculus can be applied. Two stochastic models of decreasing że pogarszanie działania zachodzi wraz z zużyciem silnika. Wtedy zachodzą kolejno stany od $\mathrm{E}_{1}$ do $\mathrm{E}_{2}$, a następnie do $E_{3}$ itd., aż do $E_{k}$, który jest stanem uniemożliwiającym dalsze działanie silnika. Z każdego zaistniałego stanu $\mathrm{E}_{\mathrm{i}}(\mathrm{i}=2,3, \ldots, \mathrm{k})$ silnik może powrócić do dowolnego stanu $\mathrm{E}_{\mathrm{i}-1}$, jeśli będzie dokonana jego odnowa $\mathrm{w}$ wyniku obsługi technicznej.

Prawdopodobieństwa zajścia stanów $\mathrm{E}_{\mathrm{i}} ; \mathrm{i}=1,2, \ldots, \mathrm{k}$ uwzględnionych $\mathrm{w}$ grafie (6) mogą być określone z zależności $(13)[7,10]$.

Przykładową realizację procesu zmniejszania energii silnika przedstawiono na rys. 7.

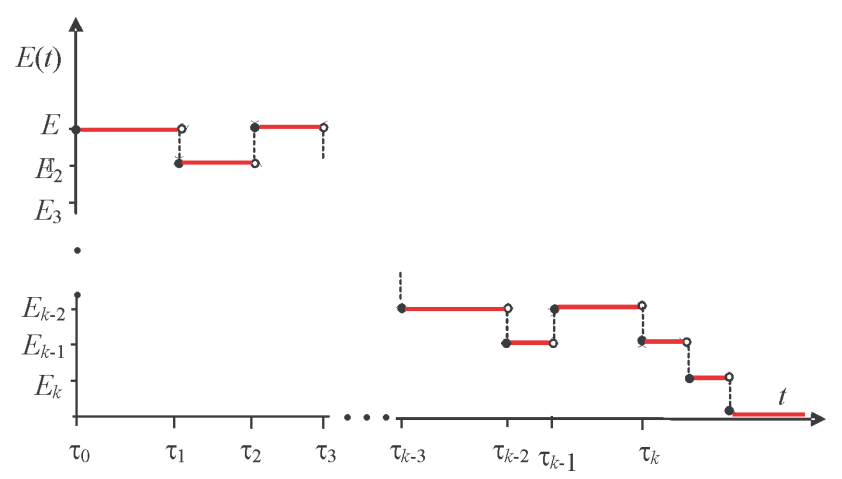

Fig. 7. An example course of the process of decreasing energy of an engine when its maintenance is possible at any time of operation Rys. 7. Przyktadowy przebieg procesu zmniejszania energii silnika, jeżeli jego odnowa będzie możliwa $w$ dowolnej chwili eksploatacji

\section{Podsumowanie}

Działanie silników spalinowych jest rozumiane jako generowanie przez nie energii $\mathrm{E} w$ określonym czasie t. Zostało ono przyrównane do wielkości fizycznej, którą można wyrazić wartością liczbową i jednostką miary nazwanej dżulosekunda [dżul $\times$ sekunda]. Działanie tak 
usable energy generated by an engine have been proposed for defining the range of operation deterioration. The first model has been presented in the form of a homogenous Poisson process and the second - in the form of a discrete state, continuous time semi-Markov process.

The operation under such an interpretation depends on the technical state of the engine and is characterized simultaneously by the energy converted by the engine and the time of the energy generation.

The advantage of the engine operation in the presented interpretation is that it can be tested by doing a precise measurement and then expressed in the form of:

- a number with the measurement unit called joule-second [joule $\times$ second] (formulas 5, 6, 7)

- a graph, as a field of operation (Fig. 2, 3 and 4).

Operation in the presented interpretation, although formulated for diesel engines, also refers to spark-ignition engines. Similar interpretation of operation can be provided for turbine combustion engines and other energetic machines.

Artykut recenzowany rozumiane ulega pogorszeniu wraz z narastaniem zużycia tego rodzaju silników. Oznacza to, że wartość tego działania, w określonym czasie, będzie maleć wskutek zmniejszania generowanej przez silnik energii. Zasygnalizowano, że w przypadku zastosowania teorii procesów stochastycznych do analizy zmian tak rozumianego działania można zastosować rachunek całkowy. Do określenia zakresu pogarszania tego działania zaproponowano dwa modele stochastyczne zmniejszania generowanej przez silnik energii użytecznej. Model pierwszy przedstawiono $\mathrm{w}$ formie jednorodnego procesu Poissona, a drugi - procesu semimarkowskiego dyskretnego w stanach i ciągłego w czasie.

Tak interpretowane działanie zależy od stanu technicznego silnika, a cechuje go jednocześnie energia przez niego przetwarzana oraz czas jej generacji.

Działanie silnika w przedstawionej wersji ma tę zaletę, że może być badane przez wykonanie precyzyjnego pomiaru, a następnie wyrażone $\mathrm{w}$ formie:

- liczby z jednostką miary nazwanej dżulosekunda $[\mathrm{dżul} \times \mathrm{se}-$ kunda] - wzory (5-7)

- graficznej, jako pole działania (rys. 2-4).

Działanie w przedstawionej interpretacji, mimo że zostało sformułowane w odniesieniu do silników o zapłonie samoczynnym, dotyczy także silników o zapłonie iskrowym. Podobną interpretację działania można przedstawić dla turbinowych silników spalinowych i innych urządzeń energetycznych.

\section{Bibliography/Literatura}

[1] Benjamin J.R., Cornell C.A.: Probability, Statistics and Decision for Civil Engineers. Copyright 1970 by McGraw-Hill, Inc. Wyd. polskie: Rachunek prawdopodobieństwa, statystyka matematyczna i teoria decyzji dla inżynierów. WNT, Warszawa 1977.

[2] Chmielniak T.J., Rusin A., Czwiertnia K.: Turbiny gazowe. Maszyny przepływowe, tom 15. Polska Akademia Nauk. Instytut Maszyn Przepływowych. Zakład Narodowy im. Ossolińskich. Wyd. PAN, Wrocław-Warszawa-Kraków 2001.

[3] Firkowicz S.: Statystyczna ocena jakości i niezawodności lamp elektronowych. WNT, Warszawa 1963.

[4] Gercbach I.B., Kordonski Ch.В.: Модели отказов. Изд. Советское Радио, Москва 1966. Wyd. polskie: Modele niezawodnościowe obiektów technicznych. WNT, Warszawa 1968.

[5] Girtler J.: Work of a compression-ignition engine as the index of its reliability and safety. II International Scientifically-Technical Conference EXPLO-DIESEL \& GAS TURBINE'01. Conference Procedings. Gdansk-Miedzyzdroje-Copenhagen 2001, pp. 70-86.

[6] Girtler J.: Conception of valuation of combustion engine operation. Journal of KONES. Powertrain and Transport. Editorial Office Institute of Aeronautics BK, Warsaw 2008, pp. 89-96.

[7] Girtler J.: Energetyczny aspekt diagnostyki maszyn. Diagnostyka nr 1(45)/2008. Wyd. Polskie Towarzystwo Diagnostyki Technicznej, Warszawa 2008, s. 149-156.

[8] Girtler J.: Diagnostyka jako warunek sterowania eksploatacją okrętowych silników spalinowych. Studia nr 28. WSM, Szczecin 1997.
[9] Girtler J.: Semi-Markov model of changes of sea-ships' and aircrafts' moving. Archives of Transport, vol. 11, iss. $1-2 / 99$ pp.

[10] Grabski F.: Teoria semimarkowskich procesów eksploatacji obiektów technicznych. Zeszyty Naukowe WSMW, nr 75A, Gdynia 1982.

[11] Niewczas A.: Podstawy stochastycznego modelu zużywania poprzez tarcie w zagadnieniach trwałości elementów maszyn. Zeszyty naukowe WSI w Radomiu, Radom 1989.

[12] Piotrowski I., Witkowski K.: Eksploatacja okrętowych silników spalinowych. AM, Gdynia 2002.

[13] Wajand J.A.: Silniki o zapłonie samoczynnym. WNT, Warszawa 1988.

[14] Wiśniewski S.: Termodynamika techniczna. WNT, Warszawa 1995.

[15] Włodarski J.K.: Tłokowe silniki spalinowe. Procesy trybologiczne. WKiŁ, Warszawa, Instytut Technologii Eksploatacji, Radom 2000.

[16] Matematyka. Kompendium. Praca zbiorowa. Świat Książki, Warszawa 2005.

Prof. Jerzy Girtler, DSc., DEng. - professor at the Faculty of Ocean Engineering and Ship Technology, Head of the Department of Ship Power Plants.

Prof. dr hab. inż. Jerzy Girtler - profesor na Wydziale Oceanotechniki i Okrętownictwa Politechniki Gdańskiej, kierownik Katedry Sitowni Okrętowych. e-mail: jgirtl@pg.gda.pl 